Article

\title{
Linking Sustainability, Embeddedness and Marketing Strategies: A Study on the Craft Beer Sector in Italy
}

\author{
Maria Cipollaro *, Sara Fabbrizzi, Veronica Alampi Sottini, Bruno Fabbri and Silvio Menghini
}

check for updates

Citation: Cipollaro, M.; Fabbrizzi, S.; Sottini, V.A.; Fabbri, B.; Menghini, S.

Linking Sustainability,

Embeddedness and Marketing

Strategies: A Study on the Craft Beer Sector in Italy. Sustainability 2021, 13, 10903. https://doi.org/10.3390/ su131910903

Academic Editors: Alessio Cappelli and Mark A. Bonn

Received: 28 July 2021

Accepted: 23 September 2021

Published: 30 September 2021

Publisher's Note: MDPI stays neutral with regard to jurisdictional claims in published maps and institutional affiliations.

Copyright: (c) 2021 by the authors. Licensee MDPI, Basel, Switzerland. This article is an open access article distributed under the terms and conditions of the Creative Commons Attribution (CC BY) license (https:// creativecommons.org/licenses/by/ $4.0 /)$.
Department of Agriculture, Food, Environment and Forestry (DAGRI), University of Florence, Piazzale delle Cascine 18, 50144 Florence, Italy; sara.fabbrizzi@unifi.it (S.F.); veronica.alampi@unifi.it (V.A.S.); bruno.fabbri@unifi.it (B.F.); silvio.menghini@unifi.it (S.M.)

* Correspondence: maria.cipollaro@unifi.it

\begin{abstract}
This paper proposes an in-depth analysis of the branding strategies implemented by agricultural craft breweries in Italy. For small-scale companies operating in the emerging craft beer sector, effective branding strategies play a key role in differentiating themselves from their competitors and gaining competitive advantages. The paper focuses on the concept of sustainability and its relation to Neolocalism. In addition, the paper analyses to what extent the craft brewing companies leverage the status of agricultural craft breweries. A mixed-method approach is adopted in the analysis. A Web Content Analysis (WebCa) led to the extrapolation of relevant information from the company websites. The data were coded according to a 1/0 binary scheme (presence/absence) and subjected to cluster analysis. The results highlight the presence of six different typologies of strategies implemented by the agricultural craft breweries, thus identifying six clusters. The six clusters differ in their emphasis on both agricultural brewery status and the components characterising the corporate brand and the attributes defining the concept of sustainability.
\end{abstract}

Keywords: Neolocalism; embeddedness; sustainability; craft beer; agricultural breweries; marketing strategies

\section{Introduction \\ 1.1. Linking Sustainability, Embeddedness and Marketing}

In recent decades, the proliferation of microbreweries has become a phenomenon on a global scale, becoming a topic of research and debate in the scientific literature [1-4].

The causes that allowed these new and very small-size breweries to penetrate a sector dominated by large multinationals have aroused particular interest in the scientific community. Many researchers have identified the change in consumer tastes towards products with marked naturalness and authenticity as the driver of the rise and spread of the phenomenon [5-8]. In particular, the concept of authenticity has gradually taken on the meaning of "local", thus identifying those products whose peculiarity is represented by the close link with a specific territory. In the scientific literature, the consumers' search for products that allow them to experience a reconnection with the places of production is called "Neolocalism" [9,10]. Neolocalism involves not only consumers but also producers [11]. When analysed from the producer's point of view, the concept of authenticity is closely linked to that of Neolocalism [12-14]. Authenticity can be considered a social construct, on the basis of which companies define their identity and the identity of their products $[12,13]$. Companies that engage in neolocal practices define their authenticity and uniqueness according to their roots and connection to a specific territory [11-13].

The concept of Neolocalism has been widely applied within the craft beer sector [11,12,15,16]. In this context, Neolocalism was described as:

" a conscious effort by businesses to foster a sense of place based on attributes of their community" [15] (p. 66) 
And also as:

A "self-conscious reassertion of the distinctively local". [17] (p. 38)

As a matter of fact, microbreweries are a good example of companies that both engage in neolocal practices [15] and can use Neolocalism to their advantage [18].

From a business perspective, "Neolocalism" encompasses a set of strategies that producers can implement to increase consumers' appreciation of their product through its connection to an exclusive place or community.

Microbreweries generally rely on such strategies to differentiate themselves in the market, using geographical names or spatial references to distinguish their company and products $[12,13]$. They also adopt symbolism aimed at evoking images of real or fictional landscapes in consumers $[19,20]$. Over time, the gradual spread of the craft beer subculture has led to the consolidation of symbology and narrative based on a sense of belonging to an alternative community, which is opposed to the mere product and general mass culture. Thus, the introduction of elements of territoriality is aimed at emphasising the aspect of exclusivity. Neolocalism, in fact, expresses a reaction to the dynamics of globalisation, which led to the concentration of beer supply in an increasingly smaller number of industries and products. However, in current demand trends, there is a growing interest in new and unique products, which would allow consumers to experience a reconnection with the production places through sharing the culture, history and traditions of the communities living there [20-22].

Neolocalism is a "holistic" concept that is applied by companies for marketing purposes [16]. However, the creation of the link with the territory is a process undertaken and carried out over time in a planned but genuine way, not aimed exclusively at selling the product $[12,16]$. This aspect was actually questioned by some authors $[16,23]$, who recognise that some companies attempt to exploit territorial cues exclusively for commercial purposes. In these cases, the link farm-territory may not necessarily be real. For the purposes of this work, it is important to emphasise that the concept of authenticity has both a nominal and a social component and that the marketing strategies implemented by microbreweries are effective if the value system guiding the company is perceived as authentic by consumers and if this finds direct expression in reality, through the actions and practices implemented by the company [12].

The relationship between marketing strategies and associated business strategies is a topic on which few scientific works have been carried out and which certainly needs to be further investigated [12,16]. In general, it is possible to highlight that in an attempt to connect with their community and to build an identity characterised by a strong link with the territory, microbreweries carry out a whole series of virtuous activities both from an environmental and social point of view [16]. Their identity becomes the expression of a deeper system of values that underlies and determines the existence of the brewery itself [24]. The contribution that microbreweries make to local and rural development is well known in the scientific literature [13,24]. According to the general strategies of multifunctional diversification, microbreweries contribute to the development of rural areas by creating networks among other businesses operating in both the agricultural and primary and secondary processing sectors, supporting and encouraging the development of local supply chains and, more generally, job creation.

Microbreweries constitute an engine for the development of more sustainable local production models based on the use of local and short-chain products and raw materials from organic farming [11]. In addition, microbreweries become an effective means for promoting and enhancing the areas in which they operate [24], actively contributing to the well-being and development of their communities. The partnerships that these small breweries create with public and private entities to support projects involving the environment, health and solidarity prove this aspect [11,25].

Neolocalism is defined as "a type of social embeddedness where notions of local commodity production, place marketing, authenticity and 'wholesomeness' are folded together in support of local craft production [24] (p. 87)". It was developed within the 
social economy [26,27], and the concept of embeddedness was adopted within economic geography, which theorised and applied it with a spatial meaning [28].

"Local embeddedness" - intended as the connections to the locality and relationships within local networks-was used to explain the success of locally clustered enterprises within the theories of Industrial Districts and Creative Milieu [29]. In the agri-food sector, the concept of embeddedness progressively developed, taking on an even broader meaning than the original one, encompassing not only the economic and social dimension of business activities but also the environmental, cultural and political dimensions [30,31]. In the scientific literature devoted to the agri-food sector and rural development, the concept of "local embeddedness" [32] was more recently applied mainly in relation to two key concepts: "localization" and "relocation" of production systems within local markets and their reintegration into the context of specific communities [33].

"Local embeddedness" was used extensively to contrast globalised production systems with unconventional ones, which are generally opposed to this model, and to define forms of Alternative Food Network [30,31,34]. For the purposes of this study, it is important to underline how the process of "relocation" and "re-grounding" (i.e., the process of reintegrating practices and products into the territorial capital) is considered a key element in ensuring sustainable production systems [35-37].

Within this framework, marketing plays a major role. Marketing is a planned process through which the company establishes its objectives and defines its business strategies, starting with the understanding of the structure of the market and the needs and expectations of consumers [35]. As for the craft beer market, factors such as brand loyalty and motivations related to sustainability, environment and support for local communities determine the consumer's willingness to buy [11]. Setting up effective marketing strategies is of strategic importance, especially for the small companies operating in the emerging craft beer sector.

One of the most effective marketing tools is branding [38-40]. A positive perception of the brand by consumers and, more broadly, by the stakeholders makes it possible to gain competitive advantages and create long-term value. Recently, the scientific literature has begun to address this topic: numerous studies analysed the marketing strategies implemented by breweries [41-43]. However, to the state of our knowledge, few contributions focused on the relationships linking the concept of Neolocalism to that of sustainability [12,13].

Through the analysis of company websites, this study aims to provide a classification of the branding strategies implemented by Italian agricultural craft breweries.

The analysis focused on Italian breweries, as the phenomenon of the rise of craft breweries has spread relatively recently, contributing to the revitalisation of a sector that had long been held back by the country's strong wine vocation. In addition, the paper focuses on a specific type of brewery, the agricultural brewery, which is required by law to produce beer from a high percentage of self-produced raw materials. The need (imposed by legislation) to produce beer from self-produced raw materials represents the prerequisite for the realisation of a farm-territory link based not only on a cultural dimension, but also on an environmental and social one [12,44-46].

The creation of an identity firmly rooted in the territory necessarily involves the search for a landscape within which to position itself [19]. To this end, companies make use of multiple references, which may include the history, folklore, cultural and natural heritage of a specific place [16]. The use of locally produced ingredients is a key element in the creation of identities characterised by a strong link with the territory. It is also an effective means by which breweries can define their authenticity [16,20]. However, in reality, this information is often omitted by craft breweries because the ingredients are sourced on international markets [44-47].

The possibility of creating business identities characterised by a strong link with the territory is made particularly difficult for craft breweries operating in Southern European countries due to the lack of both a deep-rooted brewing tradition (as in Northern European countries) and of raw materials, which are mainly imported to ensure volumes, quality 
standards and product ranges appropriate to market needs. With regard to the supply of raw materials, the companies operating in Italy seem to have adopted opposing strategies: some breweries buy the raw materials on foreign markets, while others mainly use local and regional markets to meet their production needs [46,47].

This element is relevant to the study not only in view of the fact that Italian legislation has only recently officially recognised this type of brewery but also because the recognition of agricultural breweries by the national legal system [48] as a specific type of craft brewery has aroused particular interest in both the scientific and production community. The main source of debate is whether beer can be transformed into an agricultural product while maintaining high-quality standards [47]. In 2020, the "Italian Beer Consortium" was established in Italy, and the trademark "craft from Italian agricultural supply chain" was registered. The product specification states that beer must be produced from at least $51 \%$ of raw materials of national origin [49]. The aim of the Consortium is to guarantee the origin of the raw materials and to enhance the national agricultural supply chain by promoting relationships between raw material producers (farmers) and brewers.

Agricultural breweries produce beer from cereals grown in their own farms [45]. In this sense, they can be a good example of enterprises deeply rooted in the territory, not only because they are embedded in a rural landscape but also because they are physically part of it. In addition, the production process originates right in the place where the brewery is located, making the company-territory relationship tangible [12,45]. Finally, from the point of view of sustainability, they promote activities (economic, social and environmental ones) in rural, peri-urban and/or disadvantaged areas [46,47]. The effort made by many companies to produce craft beer using raw materials of exclusively local and regional origin does not simply respond to legal requirements but also meets the demand of those consumers who are looking for beers characterised by a strong link with the local territory.

However, agricultural microbreweries target a very small niche of consumers, who are able to know and recognise an agricultural craft beer and are generally very sensitive to issues related to the environmental and social sustainability of products and production processes. For these companies, the adoption of effective marketing strategies is of crucial importance as it enables them to differentiate their products from their competitors and make their brand recognisable to consumers.

\subsection{Research Questions}

The research questions that guided the surveys were the following:

- What are the strategies implemented by the craft breweries to arouse in the consumer feelings of belonging to a community and to a specific territory?

- To what extent do the producers use the status of "agricultural craft brewery" to make their brand recognisable on the markets?

- What role does the concept of "sustainability" play in company strategies?

\subsection{Corporate Identity, Corporate Brand Identity and Corporate Website}

In the case of microbreweries, scientific studies and empirical cases show that the use of neolocal claims is an effective branding strategy only if the place brand built by the brewery is authentic, based on regional identity and a shared vision of moral values [13,42]. Authenticity is a very important characteristic of both the product and the production company, as it is on it that consumers give their preference at the time of purchase and build their loyalty. Being a social construct, the definition of authenticity varies according to time and space, but also according to the different audiences and customers that share a given context [13,42].

Authenticity is a non-objective and essentially undefinable characteristic which a stakeholder or consumer arbitrarily attributes to a product or company. However, the company can take an active and decisive role in this process, operating in such a way that a given social construct, which defines the concept of authenticity in a given context, takes on a visible and structured shape in its organisation [13,42]. For the company, creating 
"authenticity" means to define its own "identity", which visibly and explicitly possesses a set of specific characteristics, which refer to a definition of authenticity shared by a specific group and which at the same time make the company unique and immediately recognisable [42]. If the company's identity does not meet these requirements, or if the self-image it projects is evidently artificial or untrue, it will not plausibly be considered credible by the target audience, and marketing strategies will fail [13,42].

In the case of the craft beer segment, the more authentic a company is perceived to be, the more authentic is the place in which it is embedded [13]. To that end, "the craft beer brands need to be embedded within [ . . ] ] a shared socio-spatial landscape that is simultaneously a link to place, region, and the dynamics that promote sustainability" [13] (p. 3). Consequently, correct corporate identity management is a key element for the creation of a positive corporate image and reputation [38] and is fundamental for the creation/management of a brand based on the link with the territory [13]. In particular, the creation of the corporate identity is of central importance since it incorporates everything concerning communication, design, the culture of the organisation, the structure, the strategy and the behaviour of the company $[12,50]$. Depending on how this identity is perceived externally, the target audience will be able to identify a specific culture in it and, in turn, identify with it [38].

The definition of the image and the creation of the reputation takes place through communication activities. A company expresses its corporate identity by defining and communicating its corporate brand identity [51]. Companies rely on websites as one of the most widely used means of communication to convey information not only on products but also on the history, culture and values that identify the company as a whole. Websites are a tool through which companies implement their marketing strategies, leveraging both product differentiation and, above all, corporate brand differentiation [52,53]. Surfing the website becomes a real web corporate experience for a consumer who is constantly looking for information about the product and the production process, on the basis of which they can subsequently make their purchasing decisions.

\subsection{Craft Beer, Marketing and Branding}

The scientific literature specialising in economic and social disciplines has investigated the phenomenon of microbrewery proliferation internationally, and it can be divided into two main areas of research [54]. Some researchers focused on the analysis of supply, examining the structure of the market, both statically and dynamically, developing performance analyses of the sector at macro and micro levels [4,55-57]. Others, on the other hand, analysed demand, investigating the factors influencing consumer choices and preferences $[6,58]$.

More recently, part of the scientific literature has examined the marketing strategies implemented by breweries $[13,42,43]$. Most research adopted qualitative approaches, focusing on individual case studies and analysing the motivations behind the adoption of different marketing strategies and their implementation $[12,13,59,60]$. On the contrary, there are far fewer studies that addressed the topic using quantitative methodological approaches, analysing the degree to which production companies adopt strategies based on emphasising links with a specific territory. To the best of our knowledge, only one study [15] analysed the issue with a quantitative approach, formalising a "Neolocalism index" that allows a numerical value to be associated with each microbrewery. In the scientific literature, there is a rather limited number of contributions that addressed the issue of sustainability from a technical and technological point of view [61], but even more limited is the number of studies in the economic area [62].

Most of the studies that investigated marketing issues relating to the processes that guide the creation of the link between the company and the territory focused mainly on the aspects that revolve around the concept of "sense of place", concentrating primarily on the visual and symbolic dimension and exploring more marginally those relating to sustainability and embeddedness $[42,43,63,64]$. From a scientific point of view, understand- 
ing how companies use sustainability as a marketing tool is interesting because the craft beer sector has a reputation for being "green", despite a great deal of evidence showing that it actually has a strong impact on the environment, in terms of water, energy use and the creation of production waste [65]. The process through which a production company builds its corporate identity and defines its marketing strategies is necessarily linked to the concept of sustainability, since the company's reputation has become a fundamental driver of choice for consumers [66] and is based on the coherence between the system of values that the company expresses and the way in which these are concretely put into practice [67]. This aspect forces companies to undertake a transformation towards more sustainable business models [66] and to implement a whole series of practices and activities that are subsequently turned into effective marketing levers that the company can effectively use to distinguish itself from its competitors.

\section{Materials and Methods}

The Universe of agricultural breweries operating in Italy was identified from the Register of Companies [67] updated to 2020, making appropriate selections regarding the ATECO codes [68] associated with the main and secondary activities carried out by each company. The number of units surveyed is divided by geographical breakdown and is shown in Table 1.

Table 1. Sample characteristics. Our elaboration from: CCIAA—data updated to 2020.

\begin{tabular}{|c|c|c|c|c|c|c|}
\hline \multirow[t]{2}{*}{$\begin{array}{l}\text { Geographical } \\
\text { Distribution }\end{array}$} & \multicolumn{2}{|c|}{ Craft Breweries } & \multicolumn{2}{|c|}{$\begin{array}{c}\text { Agricultural } \\
\text { Craft Breweries }\end{array}$} & \multicolumn{2}{|c|}{ Sample } \\
\hline & N. & $\%$ & N. & $\%$ & N. & $\%$ \\
\hline North West & 416 & $28.87 \%$ & 58 & $33.53 \%$ & 25 & $25.77 \%$ \\
\hline North East & 308 & $21.37 \%$ & 52 & $30.06 \%$ & 34 & $35.05 \%$ \\
\hline Centre & 268 & $18.60 \%$ & 39 & $22.54 \%$ & 26 & $26.80 \%$ \\
\hline South & 449 & $31.16 \%$ & 24 & $13.87 \%$ & 12 & $12.37 \%$ \\
\hline Total & 1441 & $100 \%$ & 173 & $100 \%$ & 97 & $100 \%$ \\
\hline
\end{tabular}

A mixed-method approach was adopted. Initially, a qualitative approach was used for the extraction of information relevant to the study, followed by an analysis of this information using a quantitative approach. A Web Content Analysis (WebCa) [69] was implemented in the first phase study (qualitative phase), while the quantitative approach involved the formalisation of a cluster analysis. For the purposes of this work, the cluster analysis allowed the identification of different types of branding strategies implemented by agricultural craft breweries.

The units of analysis considered were the corporate websites as a whole. Indeed, company websites represent one of the most used means to convey information related not only to products but also to the history, culture and values that identify the company itself $[38,53,70]$. Starting from the information contained in the Chamber of Commerce's Register of Companies [67] and using the main international and national search engines, the company websites associated with each production company were identified, detecting 97 clearly active ones (56\% of the total Universe of agricultural craft breweries).

Afterward, an in-depth review of the existing scientific literature and focus groups among the members of the research group was carried out to identify some topics that contribute to describing the "Neolocal practices" implemented by agricultural craft breweries to create a corporate identity characterised by a strong territorial connotation $[12,13,15,20]$. Among the topics detected, three were considered the most important ones for the purposes of the research: (1) place identity; (2) sustainability; (3) local commodity production. Based on these, a set of attributes (Appendix A) was identified that could define the strategies implemented by the companies. The set is based on the concept of corporate brand identity $[39,40,71]$. With regard to the physical (tangible) elements that define the brand, the attributes that define the visual identity (name, logo) were considered. The products 
were also subjected to analysis, as they are the tangible manifestation of the values on which the company is based. In fact, the process of building a brand necessarily involves both the definition of the values that guide the company and the characterisation of the product [40]. Moreover, each brand is necessarily represented by "flagship" products, which are representative of the brand itself [40]. For the intangible attributes that define the brand, the elements that allow conveying information relevant to the company, such as vision, mission, history, values and corporate culture, were considered.

In order to answer the research goals, explicit references to the status of the agricultural brewery were detected through the tangible and intangible elements defining the corporate brand identity. We also proceeded to detect the presence of both physical and "invisible" items in the brand, which referred to the presence of geographical references relating to existing or imaginary places. At the same time, to detect the use or non-use of the humanisation technique, it was examined whether the microbreweries referred to animals or characters from history or local folklore in their narratives or symbology.

Within this analysis, an attribute able to operationalise the concept of "local commodity production" was included. In this work, the concept was applied mainly as a function of the origin of inputs. We focused on the origin of cereals, given their importance in beer production in both quantitative and qualitative terms. In particular, it was verified, for each of the investigated companies, whether the cereals were totally self-produced or $100 \%$ of regional or national origin. This selection was based on the fact that (1) the concept of embeddedness is scalar from a geographical perspective; (2) the product specification of the "beer from the agricultural supply chain" brand imposes the use of raw materials of national origin for at least $51 \%$ of the total [49].

Lastly, within the visible and invisible attributes that define the corporate brand identity, those elements that can be referred to as the concepts of "sustainable corporation" were detected [66], such as the adoption of green practices aimed at reducing the environmental impact of the production process and activities that aim to increase the general welfare of the community of which the company is part.

Two suitably trained and experienced researchers collected the data independently. In order to limit the critical aspects linked to the rapid change/update of the websites, the collection and coding activities were organised so as to be concentrated in no more than two months' time (May to June 2019) [69]. In order to test the reliability of the coding, a pilot study was conducted in the training phase. A percentage of websites $(15 \%)$ were randomly selected, and researchers were asked to carry out the analysis simultaneously on the same units. The intercoder reliability [72] calculated from the data collected revealed a high degree of agreement between coders $(>85 \%)$.

The information collected was coded according to a binary scoring system $(1 ; 0$ presence/absence) and organised in a purpose-built database. The information was reclassified according to the scheme in Table 2 and processed through a Hierarchical cluster analysis.

The cluster analysis was conducted by applying Ward's method to the dissimilarity matrix calculated from the raw data using the simple matching coefficient [73]. The silhouette average width criterion was adopted to define the optimal number of clusters [74].

The analyses were carried out using the Proxy Package [75], the Cluster Package [76] and the Nbclust Package [77] developed in the R environment [78]. 
Table 2. Set of attributes selected for the investigation.

\begin{tabular}{|c|c|c|c|c|}
\hline Dimension & Attribute & Code & Description & References \\
\hline \multirow{7}{*}{ Place identity } & \multirow{7}{*}{$\begin{array}{l}\text { Tangible/(Physical) attributes } \\
\text { agricultural craft brewery }\end{array}$} & \multirow{7}{*}{ Tangible_a } & \multirow{7}{*}{$\begin{array}{l}\text { References to the status of agricultural brewery in the } \\
\text { company name or logo. } \\
\text { References to the status of agricultural beer in the name, } \\
\text { label or description. }\end{array}$} & [38] \\
\hline & & & & [64] \\
\hline & & & & [12] \\
\hline & & & & [63] \\
\hline & & & & [20] \\
\hline & & & & [15] \\
\hline & & & & [59] \\
\hline \multirow{4}{*}{ Place identity } & \multirow{4}{*}{$\begin{array}{c}\text { Intangible } \\
\text { attributes } \\
\text { agricultural craft brewery }\end{array}$} & \multirow{4}{*}{ Intangible_a } & \multirow{4}{*}{$\begin{array}{l}\text { References to the status of agricultural brewery in the } \\
\text { description of the vision, mission, values and } \\
\text { corporate "history". }\end{array}$} & [38] \\
\hline & & & & [12] \\
\hline & & & & [59] \\
\hline & & & & [63] \\
\hline \multirow{3}{*}{ Place identity } & \multirow{3}{*}{$\begin{array}{l}\text { Tangible/(Physical) attributes } \\
\text { Sense of place }\end{array}$} & \multirow{3}{*}{ Tangible_sp } & \multirow{3}{*}{$\begin{array}{l}\text { Use of place names or geographical references in the } \\
\text { company name or logo. } \\
\text { Use of the "humanisation" technique. } \\
\text { Reference to the independent craft beer sector. }\end{array}$} & [24] \\
\hline & & & & {$[20]$} \\
\hline & & & & [15] \\
\hline \multirow{3}{*}{ Place identity } & \multirow{3}{*}{$\begin{array}{l}\text { Intangible } \\
\text { Attributes } \\
\text { Sense of place }\end{array}$} & \multirow{3}{*}{ Intangible_sp } & \multirow{3}{*}{$\begin{array}{l}\text { Use of place names or geographical references in the } \\
\text { description of vision, mission, values and } \\
\text { corporate history. }\end{array}$} & {$[24]$} \\
\hline & & & & [20] \\
\hline & & & & [15] \\
\hline \multirow{4}{*}{$\begin{array}{l}\text { Local commodity } \\
\text { Production }\end{array}$} & \multirow{4}{*}{ Local commodity production } & \multirow{4}{*}{$\begin{array}{l}\text { Local commodity } \\
\text { production }\end{array}$} & \multirow{4}{*}{$\begin{array}{l}100 \% \text { Self-produced raw materials. } \\
100 \% \text { Local/National/regional origin of raw materials. }\end{array}$} & [24] \\
\hline & & & & {$[20]$} \\
\hline & & & & [15] \\
\hline & & & & [49] \\
\hline \multirow{3}{*}{ Sustainability } & \multirow{3}{*}{$\begin{array}{l}\text { Environmental sustainability } \\
\text { Social sustainability }\end{array}$} & \multirow{3}{*}{ Sustainability } & \multirow{3}{*}{$\begin{array}{l}\text { The brewery implements practices to limit the } \\
\text { environmental impact of production. } \\
\text { The brewery produces organic beer. } \\
\text { The brewery implements socially sustainable practices. }\end{array}$} & [15] \\
\hline & & & & [79] \\
\hline & & & & [66] \\
\hline
\end{tabular}

\section{Results}

Table 3 summarises the frequencies of the attributes investigated. In percentage, the attributes related to the status of the agricultural brewery are associated with frequencies of more than $50 \%$ (Tangible_a) and 60\% (Intangible_a), respectively. Moreover, almost all companies include territorial cues in the attributes that define the tangible (Tangible_sp) and intangible dimensions (Intangible_sp) of the corporate brand.

Attributes related to the origin of raw materials (local commodity production) are associated with a frequency of $76 \%$, The sustainability-related attributes (sustainability), considering both "social sustainability" and "environmental sustainability", are associated with low frequencies $(26.80 \%)$.

Table 3. Descriptive analysis.

\begin{tabular}{ccccc}
\hline Attribute & \multicolumn{2}{c}{$\begin{array}{c}\text { Absolute } \\
\text { Values }\end{array}$} & $\mathbf{2}$ & \multicolumn{2}{c}{$\begin{array}{c}\text { Percentage } \\
\text { Values }\end{array}$} \\
\hline & $\mathbf{1}$ & $\mathbf{0}$ & $\mathbf{1}$ & $\mathbf{0}$ \\
\hline Intangible_a & 68 & 29 & $70.10 \%$ & $29.90 \%$ \\
Tangible_a & 57 & 40 & $58.76 \%$ & $41.24 \%$ \\
Intangible_sp & 91 & 6 & $93.81 \%$ & $6.19 \%$ \\
Tangible_sp & 89 & 8 & $91.75 \%$ & $8.25 \%$ \\
Local commodity & 74 & 23 & $76.29 \%$ & $23.71 \%$ \\
Production & 26 & 71 & $26.80 \%$ & $73.20 \%$ \\
Sustainability & & &
\end{tabular}

According to the research questions and the results obtained from the descriptive analysis, which showed that almost all breweries include spatial references in the compo- 
nents defining the brand, the cluster analysis was carried out on four of the six variables considered (Intangible_a, Tangible_a, local commodity production, sustainability).

The cluster analysis (Table 4) identified six homogeneous groups of companies, according to the selected variables (average silhouette width $>0.70$ ), which presumably correspond to different branding strategies: (1) place and raw materials origin; (2) status of agricultural breweries and product characteristics; (3) 100\% agricultural breweries; (4) status of agricultural brewery, culture and identity; (5) sustainable breweries; (6) values, culture and products.

(1) Place and Raw materials origin

Cluster $1(n=23)$ is characterised by the total absence of references to the status of "agricultural brewery" in the attributes that make up the intangible attributes of the corporate brand. Moreover, less than $20 \%$ of the breweries include reference to the status of "agricultural breweries" in the elements that define the tangible attribute of the brand. Most of the breweries $(60 \%)$ provide information on the origin of raw materials, while only $10 \%$ of them provide information related to the introduction of "green" practices or to corporate social responsibility.

(2) Status of agricultural breweries and product characteristics

Cluster 2 represents the most numerous cluster $(n=25)$. All companies declare the status of the agricultural brewery in the attributes that make up both the intangible and tangible attributes of the corporate brand. Moreover, all the breweries provide information about the origin of raw materials. None of them include information on the adoption of environmentally or socially sustainable practices.

(3) $100 \%$ agricultural breweries

With regard to Cluster $3(n=13)$, all companies declare the status of the agricultural brewery in the attributes defining both the intangible and tangible components of the corporate brand. Furthermore, all companies emphasise the origin of raw materials and include information regarding the implementation of environmentally or socially sustainable practices on the website.

(4) Status of agricultural brewery, culture and identity

With regard to cluster $4(n=15)$, all companies declare the status of the agricultural brewery in the elements that define both the intangible and tangible components of the corporate brand. However, none of them include information on the origin of raw materials, on the introduction of "green" practices or on corporate social responsibility.

\section{(5) Sustainable breweries}

In cluster $5(n=11)$, less than half of the breweries declare the status of an agricultural microbrewery in the elements defining the intangible components of the corporate brand. In addition, none of them include this information in the components defining the tangible components of the brand. All the breweries include information regarding both the origin of raw materials and the implementation of practices to limit the negative impacts of the production process on the environment or refer to socially sustainable practices.

(6) Values, culture and products

Cluster $6(n=10)$ represents the least numerous cluster. All the breweries declare the status of agricultural brewery in the definition of the intangible elements of the corporate brand, but none of them specify the status of agricultural brewery in the elements that define the tangible attribute of the brand. All the breweries emphasise the origin of raw materials, while none of them include information regarding the implementation of sustainable practices on the website. 
Table 4. Hierarchical clustering analysis.

\begin{tabular}{|c|c|c|c|c|c|}
\hline Cluster & Value & $\begin{array}{c}\text { Intangible } \\
\text { Agricultural Brewery }\end{array}$ & $\begin{array}{c}\text { Tangible } \\
\text { Agricultural Brewery }\end{array}$ & $\begin{array}{l}\text { Local Commodity } \\
\text { Production }\end{array}$ & Sustainability \\
\hline Cluster 1 & 1 & $0 \%$ & $17 \%$ & $65 \%$ & $9 \%$ \\
\hline $\mathrm{N}=23$ & 0 & $100 \%$ & $83 \%$ & $35 \%$ & $91 \%$ \\
\hline Cluster 2 & 1 & $100 \%$ & $100 \%$ & $100 \%$ & $0 \%$ \\
\hline $\mathrm{N}=25$ & 0 & $0 \%$ & $0 \%$ & $0 \%$ & $100 \%$ \\
\hline Cluster 3 & 1 & $100 \%$ & $100 \%$ & $100 \%$ & $100 \%$ \\
\hline $\mathrm{N}=13$ & 0 & $0 \%$ & $0 \%$ & $0 \%$ & $0 \%$ \\
\hline Cluster 4 & 1 & $100 \%$ & $100 \%$ & $0 \%$ & $0 \%$ \\
\hline $\mathrm{N}=15$ & 0 & $0 \%$ & $0 \%$ & $100 \%$ & $100 \%$ \\
\hline Cluster 5 & 1 & $45 \%$ & $0 \%$ & $100 \%$ & $100 \%$ \\
\hline $\mathrm{N}=11$ & 0 & $0 \%$ & $100 \%$ & $0 \%$ & $0 \%$ \\
\hline Cluster 6 & 1 & $100 \%$ & $0 \%$ & $100 \%$ & $0 \%$ \\
\hline $\mathrm{N}=10$ & 0 & $0 \%$ & $100 \%$ & $0 \%$ & $100 \%$ \\
\hline
\end{tabular}

\section{Discussion}

This study deepens the knowledge of the branding strategies implemented by agricultural craft breweries in Italy as a means to position themselves in specific market niches successfully. In particular, the research focuses on two main aspects: sustainability and the status of craft agricultural breweries.

In general, the results obtained allowed us to highlight that the companies under study are strongly oriented towards building a corporate brand based on the link with the territory $[12,15,20]$. In pursuit of this goal, almost all the breweries emphasise the intangible aspects of the corporate brand, devoting particular attention to the description of the company's history and the definition of the brewery's mission and vision and, more generally, the description of the values that guide them. Territorial cues are also strongly employed in the elements defining the tangible component of the corporate brand (visual identity and the product). Companies build their corporate brand by sharing elements of the culture and tradition of the territory in which they reside. The cultural, natural and symbolic heritage of the territory is also used to define the visual component of the brand: companies refer to distinctive features of the territory in which they are and use toponyms or references to real or imaginary places to characterise the name of the enterprise and the products. The result is in line with the existing literature $[12,15,20]$ and reveals that the analysed breweries also make strong use of neolocal strategies. This aspect is also relevant if one considers that a much smaller but a high percentage of breweries include references to the status of an agricultural brewery in the brand components. Omitting this information means making the agricultural craft brewery potentially indistinguishable from other types of microbreweries.

With regard to the status of an agricultural craft brewery, it is mainly emphasised in the attributes that define the intangible components of the brand rather than in the components defining the tangible ones. In this case, the inclusion of references to the status of a brewery allows the company not only to identify its own reality and distinguish it from other types of production (in order to comply with the law), but it characterises the product in the market.

The land that craft breweries cultivate makes it possible to identify the farms and to place them materially in a geographically defined space. However, even if this aspect is very important, being "craft breweries" means also that these companies embody and share the values, culture and history of the rural and farming world in which they are located.

The company-territory link is also strongly emphasised by including information about the origin of raw materials. More than $70 \%$ of the breweries include information about raw materials: this result becomes even more relevant in view of the fact that the 
analysis was limited to the use of cereals. Moreover, only information about $100 \%$ selfproduced cereals or $100 \%$ cereals from a national agricultural chain were collected. The attributes defining the "local commodity production" describe the "regrounded" process of the production processes, becoming an expression both of the territorial dimension of the breweries and of the sustainability one.

Finally, the study reveals that less than $30 \%$ of the companies analysed provide information on the introduction of green practices or on the company's corporate social responsibility. The results of the study show that the companies emphasise the origin of raw materials rather than the introduction of a greener production process and the social component of sustainability.

The cluster analysis (carried out on four of the six selected variables) identified six different types of strategies implemented by the production companies: (1) place and raw materials origin, (2) status of agricultural breweries and product characteristics, (3) $100 \%$ agricultural breweries, (4) status of agricultural brewery culture and identity, (5) sustainable breweries, (6) values, culture and products.

Cluster (1) - place and raw materials origin —is characterised by the emphasis given to the origin of raw materials. In Cluster (2) - status of agricultural breweries and product characteristics - the status of agricultural brewery is emphasised in the attributes defining both the tangible and intangible components of the corporate brand; in addition, the cluster is characterised by the emphasis given to the origin of raw materials. Cluster (3) - $100 \%$ agricultural breweries-is characterised by the focus given to the status of an agricultural brewery. In Cluster (4) - status of agricultural brewery, culture and identity-all the companies declare the status of an agricultural brewery in the elements that define both the intangible and tangible components of the corporate brand. The cluster differs from Cluster (3) because information concerning raw materials is missing. Cluster (5)-sustainable breweries-clearly shows the attempt of companies to base their branding strategies on the concept of sustainability. Finally, Cluster (6) - values, culture and products-is characterised by the emphasis given both to the intangible component of the corporate brand and the origin of raw materials.

It is interesting to highlight that three clusters (Cluster 2, Cluster 3, Cluster 4) are represented by companies declaring the status of an agricultural brewery and differ in the presence or absence of references to the origin of raw materials and the implementation of green practices. The other three clusters (Cluster 1, Cluster 5 and Cluster 6) are more difficult to describe. The main differences concern the presence or absence of references to the status of an agricultural brewery in the attributes defining the tangible and intangible components of the brand. Furthermore, the origin of raw materials is widely emphasised in all three clusters, whereas two of the three clusters omit information on sustainability.

\section{Conclusions, Main Limitations, Future Research Opportunities}

The research provides a contribution to the emerging literature on branding strategies implemented by craft breweries. In particular, the work deals with the concept of sustainability, thus contributing to filling a gap in the literature. In addition, the study focuses on the status of the agricultural brewery, not only as a further element of differentiation from competitors but also as a type of brewery in which the farm-territory link takes on a real dimension.

The results of the survey showed the presence of different strategies implemented by the breweries: most of them carry out branding strategies based mainly on the emphasis on the sense of place and the status of agricultural breweries in the elements defining both the tangible and intangible components of a corporate brand. The aspects related to sustainability are considered of lesser importance. As a fact, companies tend to strongly emphasise aspects relating to the origin of raw materials while neglecting those relating to the environment and social dimension of sustainability.

Although the results cannot be generalised, they lay the foundations for future research on the subject. Moreover, the study provides useful insights for the production world: 
leveraging the concepts of sustainability represents a strategy that allows companies to reach and retain consumer niches, potentially expanding the market not only to those who support Neolocalism but also to the niche of Lohas consumers [9]. It might be interesting to approach the issue from a financial perspective to verify to what extent the construction of a brand identity based on the concept of Neolocalism and sustainability creates economic value for the company. Evaluating the role played by different stakeholders in the brand co-creation process [80] could be a further research topic. In addition, it is also important to complement studies on producers with studies on consumers, using brand equity-based models to analyse how sustainability influences consumer preference when purchasing products [81] and their attitudes towards the brand.

The paper is part of the extensive scientific literature dealing with the analysis of corporate websites for marketing and strategic management purposes. The importance of the internet as a market channel and of websites as a corporate communication tool is widely acknowledged. However, as this is a qualitative analysis carried out in a virtual environment, the research conducted here presents limitations which it is important to point out: (i) the medium analysed; (ii) the nature of the data obtained; (iii) the subjectivity and ambiguity that in some cases may characterise the information acquired from websites. Moreover, another limitation concerns the framework and the coding system employed.

The framework adopted for the collection of relevant information for the study was developed from three dimensions that define the concept of Neolocalism-space identity, local commodity production and sustainability.

In order to adequately answer the research questions, the research focused mainly on two of the three concepts identified: local commodity production and sustainability. The "place identity" dimension was analysed mainly in relation to the type of microbrewery investigated, i.e., the agricultural craft brewery. Moreover, the use of binary variables and the reclassification of the data (necessary to classify and characterise the strategies implemented by the breweries investigated) led to further simplifications. The research does not pretend to be exhaustive. The implementation of the study to other types of microbreweries might be an important step to take in the near future, as it could allow comparisons between them and highlight possible differences. To this end, the framework can be extended by identifying further attributes that define the concept of Neolocalism and sustainability.

Author Contributions: Conceptualisation, S.F., M.C. and S.M.; methodology, S.F., M.C. and S.M.; software, M.C. and S.M.; validation, S.F., V.A.S., B.F., M.C. and S.M.; formal analysis, B.F., M.C. and S.M.; investigation, B.F. and M.C.; resources, S.F., B.F., V.A.S., M.C. and S.M.; data curation, B.F. and M.C.; writing—original draft preparation, M.C. and V.A.S.; writing—review and editing, V.A.S.; visualisation, S.F., V.A.S., B.F., M.C. and S.M.; supervision, S.M.; project administration, M.C. and S.M. All authors have read and agreed to the published version of the manuscript.

Funding: This research received no external funding.

Institutional Review Board Statement: Not applicable.

Informed Consent Statement: Not applicable.

Data Availability Statement: Data are available with authors upon request.

Conflicts of Interest: The authors declare no conflict of interest. 


\section{Appendix A}

\begin{tabular}{|c|c|c|c|}
\hline & Neolocalism Dimension & Code & Attribute \\
\hline 1. & Place identity & $\begin{array}{c}\text { Intangible } \\
\text { (agricultural brewery) }\end{array}$ & $\begin{array}{l}\text { Vision, mission, about us-Does the brewery declare the } \\
\text { status of agricultural brewery? }\end{array}$ \\
\hline 2. & Place identity & $\begin{array}{l}\text { Tangible } \\
\text { (agricultural brewery) }\end{array}$ & $\begin{array}{l}\text { Name-Is there any reference e to the status of } \\
\text { agricultural brewery in the company name? }\end{array}$ \\
\hline 3. & Place identity & $\begin{array}{l}\text { Tangible } \\
\text { (agricultural brewery) }\end{array}$ & $\begin{array}{l}\text { Logo-Is there any reference to the status of agricultural } \\
\text { brewery in the company logo? }\end{array}$ \\
\hline 4. & Place identity & $\begin{array}{l}\text { Tangible } \\
\text { (agricultural brewery) }\end{array}$ & $\begin{array}{l}\text { Product-Does the name of the products refer to } \\
\text { agricultural beer? }\end{array}$ \\
\hline 5. & Place identity & $\begin{array}{c}\text { Tangible } \\
\text { (agricultural brewery) }\end{array}$ & $\begin{array}{l}\text { Product-Is there any reference to the status of } \\
\text { "agricultural beer" in the product label? } \\
\text { Is there any reference to agricultural beer in the product } \\
\text { label? }\end{array}$ \\
\hline 6. & Place identity & $\begin{array}{l}\text { Tangible } \\
\text { (agricultural brewery) }\end{array}$ & $\begin{array}{l}\text { Product- Is there any reference to the status of } \\
\text { agricultural brewery in the product description? }\end{array}$ \\
\hline 7. & Place identity & $\begin{array}{c}\text { Intangible } \\
\text { (sense of place) }\end{array}$ & $\begin{array}{l}\text { Vision, mission, about us-Does the brewery include } \\
\text { any geographical reference relating to existing or } \\
\text { imaginary places? } \\
\text { Does the brewery refer to animals or characters from } \\
\text { history or local folklore in its narratives or symbology? } \\
\text { Does the brewery claim to belong to the independent } \\
\text { brewing sector? }\end{array}$ \\
\hline 8. & Place identity & $\begin{array}{c}\text { Tangible } \\
\text { (sense of place) }\end{array}$ & $\begin{array}{l}\text { Name-Is there any geographical reference relating to } \\
\text { existing or imaginary places in the company name? } \\
\text { Is there any reference to animals or characters from } \\
\text { history or local folklore in the company name? } \\
\text { Is there any reference to the independent brewing sector } \\
\text { in the company name? }\end{array}$ \\
\hline 9. & Place identity & $\begin{array}{c}\text { Tangible } \\
\text { (sense of place) }\end{array}$ & $\begin{array}{l}\text { Logo-Is there any geographical reference relating to } \\
\text { existing or imaginary places in the company logo? Is } \\
\text { there any reference to animals or characters from history } \\
\text { or local folklore in the company logo? } \\
\text { Is there any reference regarding membership of the } \\
\text { independent brewing sector in the company logo? }\end{array}$ \\
\hline 10. & Place identity & $\begin{array}{c}\text { Tangible } \\
\text { (sense of place) }\end{array}$ & $\begin{array}{l}\text { Product-Is there any geographical reference relating to } \\
\text { existing or imaginary places in the product name? } \\
\text { Is there any reference to animals or characters from } \\
\text { history or local folklore in the product name? } \\
\text { Is there any reference to the independent brewing sector } \\
\text { in the product name? }\end{array}$ \\
\hline 11. & Place identity & Tangible & $\begin{array}{l}\text { Product-Is there any geographical reference relating to } \\
\text { existing or imaginary places in the product label? } \\
\text { Is there any reference to animals or characters from } \\
\text { history or local folklore in the product label? } \\
\text { Is there any reference to the independent brewing sector } \\
\text { in the product label? }\end{array}$ \\
\hline 12. & Place identity & $\begin{array}{c}\text { Tangible } \\
\text { (sense of place) }\end{array}$ & $\begin{array}{l}\text { Product-Is there any geographical reference relating to } \\
\text { existing or imaginary places in the product description? } \\
\text { Is there any reference to animals or characters from } \\
\text { history or local folklore in the product description? } \\
\text { Is there any reference to the independent brewing sector } \\
\text { in the product description? }\end{array}$ \\
\hline
\end{tabular}

13. Local commodity production
Local commodity production
Are the cereals $100 \%$ self-produced? 


\begin{tabular}{|c|c|c|c|}
\hline & Neolocalism Dimension & Code & Attribute \\
\hline 14. & Local commodity production & Local commodity production & Are the cereals $100 \%$ locally sourced? \\
\hline 15. & Local commodity production & Local commodity production & Are the cereals $100 \%$ of regional origin? \\
\hline 16. & Local commodity production & Local commodity production & Are the cereals $100 \%$ of national origin? \\
\hline 17. & Sustainability & Environmental dimension & $\begin{array}{l}\text { Does the company implement any water sustainability } \\
\text { use program? }\end{array}$ \\
\hline 18. & Sustainability & Environmental dimension & $\begin{array}{l}\text { Does the company implement programmes to use } \\
\text { energy from renewable sources? }\end{array}$ \\
\hline 19. & Sustainability & Environmental dimension & $\begin{array}{l}\text { Does the company implement any waste reduction } \\
\text { program? }\end{array}$ \\
\hline 20. & Sustainability & Environmental dimension & $\begin{array}{l}\text { Does the company use raw materials from organic } \\
\text { farming? }\end{array}$ \\
\hline 21. & Sustainability & Environmental dimension & Does the company produce organic beer? \\
\hline 22. & Sustainability & Social dimension & $\begin{array}{l}\text { Does the brewery support local non-profit } \\
\text { organisations? }\end{array}$ \\
\hline 23. & Sustainability & Social dimension & $\begin{array}{l}\text { Does the brewery create economic relations with other } \\
\text { local producers? }\end{array}$ \\
\hline 24. & Sustainability & Social dimension & $\begin{array}{l}\text { Does the brewery create non-economic relations with } \\
\text { other local producers? }\end{array}$ \\
\hline
\end{tabular}

\section{References}

1. Cabras, I. Craft beer in the EU: Exploring different markets and systems across the continent. In The Geography of Beer; HoalstPullen, N., Patterson, M., Eds.; Springer: Cham, Switzerland, 2020; pp. 149-157.

2. Garavaglia, C. The birth and diffusion of craft breweries in Italy. In Economic Perspectives on Craft Beer; Palgrave Macmillan: Cham, Switzerland, 2018; pp. 229-258.

3. Garavaglia, C.; Swinnen, J. Economics of the craft beer revolution: A comparative international perspective. In Economic Perspectives on Craft Beer; Palgrave Macmillan: Cham, Switzerland, 2018; pp. 3-51.

4. Tremblay, V.J.; Iwasaki, N.; Tremblay, C.H. The dynamics of industry concentration for US micro and macro brewers. Rev. Ind. Organ. 2005, 26, 307-324. [CrossRef]

5. Cabras, I.; Bamforth, C. From reviving tradition to fostering innovation and changing marketing: The evolution of micro-brewing in the UK and US, 1980-2012. Bus. Hist. 2016, 58, 625-646. [CrossRef]

6. Donadini, G.; Porretta, S. Unconvering patterns of consumers' interest for beer: A case study with craft beers. Food Res. Int. 2017, 91, 183-198. [CrossRef] [PubMed]

7. Fastigi, M.; Viganò, E.; Esposti, R. The Italian microbrewing experience: Features and perspectives. Bio-Based Appl. Econ. 2018, 7, $59-86$.

8. Gómez-Corona, C.; Escalona-Buendía, H.B.; García, M.; Chollet, S.; Valentin, D. Craft vs. industrial: Habits, attitudes and motivations towards beer consumption in Mexico. Appetite 2016, 96, 358-367. [CrossRef]

9. Patton, M.T.; Mathews, A.J. Marketing American microbrews: Promoting neolocalism one map at a time. Pap. Appl. Geogr. 2013, $36,17-26$.

10. Shortridge, J.R. Keeping tabs on Kansas: Reflections on regionally based field study. J. Cult. Geogr. 1996, 16, 5-16. [CrossRef]

11. Graefe, D.; Mowen, A.; Graefe, A. Craft beer enthusiasts' support for neolocalism and environmental causes. In Craft Beverages and Tourism; Palgrave Macmillan: Cham, Switzerland, 2018; Volume 2, pp. 27-47.

12. Melewar, T.C.; Skinner, H. Territorial brand management: Beer, authenticity, and sense of place. J. Bus. Res. 2020, 116, 680-689. [CrossRef]

13. Gatrell, J.; Reid, N.; Steiger, T.L. Branding spaces: Place, region, sustainability and the American craft beer industry. Appl. Geogr. 2018, 90, 360-370. [CrossRef]

14. Honkaniemi, T.; Syrjälä, H.; Lundström, N.; Rajala, A. Neolocalism and Beyond--Sexing Up Rural Places. Rural. Sociol. 2021, 86, 326-356. [CrossRef]

15. Holtkamp, C.; Shelton, T.; Daly, G.; Hiner, C.C.; Hagelman, R., III. Assessing neolocalism in microbreweries. Pap. Appl. Geogr. 2016, 2, 66-78. [CrossRef] 
16. Ikäheimo, J.P. Arctic narratives: Brewing a brand with neolocalism. J. Brand Manag. 2021, 28, 374-387. [CrossRef]

17. Flack, W. American Microbreweries and Neolocalism: "Ale-ing" for a Sense of Place. J. Cult. Geogr. 1997, 16, 37-53. [CrossRef]

18. Taylor, S., Jr.; DiPietro, R.B. Segmenting craft beer drinkers: An analysis of motivations, willingness to pay, and repeat patronage intentions. Int. J. Hosp. Tour. Adm. 2019, 20, 423-448. [CrossRef]

19. Baker, J.E. On the bottle: Situating place-based discourses in global production networks-a visual and textual analysis of craft beer labels. AUC Geogr. 2019, 54, 3-14. [CrossRef]

20. Schnell, S.M.; Reese, J.F. Microbreweries as tools of local identity. J. Cult. Geogr. 2003, 21, 45-69. [CrossRef]

21. Fastigi, M.; Cavanaugh, J.R. Turning passion into profession: A history of craft beer in Italy. Gastronomica 2017, 17, 39-50. [CrossRef]

22. Fastigi, M.; Esposti, R.; Orazi, F.; Viganò, E. The irresistible rise of the craft brewing sector in Italy: Can we explain it. In Proceedings of the 4th AIEAA Conference "Innovation, Productivity and Growth: Towards Sustainable Agri-Food Production", Ancona, Italy, 11-12 June 2015; pp. 1-22.

23. Thurnell-Read, T. A thirst for the authentic: Craft drinks producers and the narration of authenticity. Br. J. Sociol. 2019, 70, 1448-1468. [CrossRef]

24. Argent, N. Heading down to the local? Australian rural development and the evolving spatiality of the craft beer sector. J. Rural. Stud. 2018, 61, 84-99. [CrossRef]

25. Sforzi, J.; Colombo, L.A. New Opportunities for Work Integration in Rural Areas: The 'Social Flavour'of Craft Beer in Italy. Sustainability 2020, 12, 6351. [CrossRef]

26. McKeever, E.; Anderson, A.; Jack, S. Social embeddedness in entrepreneurship research: The importance of context and community. In Handbook of Research on Small Business and Entrepreneurship; Edward Elgar Publishing: Jottham College, UK, 2014.

27. Polanyi-Levitt, K. (Ed.) The Life and Work of Karl Polanyi. A Celebration; Black Rose Book: Montréal, QC, Canada, 1900.

28. Martin, R. Economic theory and human geography. In Human Geography; Palgrave: London, UK, 1994; pp. 21-53.

29. Hess, M. 'Spatial' relationships? Towards a reconceptualization of embeddedness. Prog. Hum. Geogr. 2004, 28, 165-186. [CrossRef]

30. Sonnino, R. Embeddedness in action: Saffron and the making of the local in southern Tuscany. Agric. Hum. Values 2007, 24, 61-74. [CrossRef]

31. Murdoch, J.; Marsden, T.; Banks, J. Quality, nature, and embeddedness: Some theoretical considerations in the context of the food sector. Econ. Geogr. 2000, 76, 107-125. [CrossRef]

32. Whatmore, S.; Thorne, L. Nourishing Networks: Alternative Geographies of Food; Routledge: London, UK, 2013 ; pp. $222-235$.

33. Goodman, D. Rural Europe redux? Reflections on alternative agro-food networks and paradigm change. Sociol. Rural. 2004, 44, 3-16. [CrossRef]

34. Winter, M. Embeddedness, the new food economy and defensive localism. J. Rural. Stud. 2003, 19, 23-32. [CrossRef]

35. Horlings, L.G.; Marsden, T.K. Exploring the 'New Rural Paradigm'in Europe: Eco-economic strategies as a counterforce to the global competitiveness agenda. Eur. Urban Reg. Stud. 2014, 21, 4-20. [CrossRef]

36. Roep, D.; Wiskerke, J.S. On governance, embedding and marketing: Reflections on the construction of alternative sustainable food networks. J. Agric. Environ. Ethics 2012, 25, 205-221. [CrossRef]

37. Van der Ploeg, J.D. Agricultural production in crisis. In Handbook of Rural Studies; Sage Publications: London, UK, 2006; pp. 258-278.

38. Balmer, J.M. Corporate identity and the advent of corporate marketing. J. Mark. Manag. 1998, 14, 963-996. [CrossRef]

39. Balmer, J.M.; Gray, E.R. Corporate brands: What are they? What of them? Eur. J. Mark. 2003, 37, 972-997. [CrossRef]

40. Kapferer, J.N. The New Strategic Brand Management: Creating and Sustaining Brand Equity Long Term; Kogan Page Publishers: London, UK, 2008.

41. Cannatelli, B.; Pedrini, M.; Grumo, M. The effect of brand management and product quality on firm performance: The Italian craft brewing sector. J. Food Prod. Mark. 2017, 23, 303-325. [CrossRef]

42. Carol, Y.Z.; Federico, G.; Thomas, M.B. Competitiveness in a saturated market. A case study of the Scottish craft beer industry. Int. J. Bus. Soc. Sci. 2015, 6, 28-46.

43. Mathews, A.J.; Patton, M.T. Exploring place marketing by American microbreweries: Neolocal expressions of ethnicity and race. J. Cult. Geogr. 2016, 33, 275-309. [CrossRef]

44. Cipollaro, M.; Sottini, V.A.; Fabbrizzi, S. The role of the raw materials in the development of a Tuscan craft beer chain. Ital. Rev. Agric. Econ. 2018, 73, 53-64.

45. Cipollaro, M.; Sottini, V.A.; Fabbrizzi, S. Beer farms in Tuscany: A case study. In Case Studies in the Beer Sector; Woodhead Publishing: Shaxton, UK, 2021; pp. 165-181.

46. Francioni, B.; Viganò, E. Craft and agricultural brewing in the Marche region: Theoretical and empirical implications of global versus local sourcing. In Case Studies in the Beer Sector; Woodhead Publishing: Shaxton, UK, 2021; pp. 183-200.

47. Francioni, B.; Curina, I.; Masili, G.; Viganò, E. Global sourcing processes in the Italian agricultural breweries. Br. Food J. 2019, 121, 2277-2295. [CrossRef]

48. LEGGE 28 luglio 2016, n. 154. Deleghe al Governo e ulteriori disposizioni in materia di semplificazione, razionalizzazione e competitività dei settori agricolo e agroalimentare, nonché sanzioni in materia di pesca illegale (16G00169). Anno 157, numero 186. G.U. Gazzetta Ufficiale della Repubblica Italiana. 2016. Available online: http:/ / extwprlegs1.fao.org/docs/pdf/ita161711.pdf (accessed on 24 September 2021). 
49. Coldiretti. Birra, Presentato Il Nuovo Logo "Artigianale Da Filiera Agricola Italiana". 2020. Available online: https://www. coldiretti.it/economia/birra-presentato-il-nuovo-logo-artigianale-da-filiera-agricola-italiana (accessed on 24 September 2021).

50. Abratt, R.; Kleyn, N. Corporate identity, corporate branding and corporate reputations: Reconciliation and integration. Eur. J. Mark. 2012, 46, 1048-1063. [CrossRef]

51. Balmer, J.M.; Greyser, S.A. Corporate marketing: Integrating corporate identity, corporate branding, corporate communications, corporate image and corporate reputation. Eur. J. Mark. 2006, 40, 730-741. [CrossRef]

52. Balmer, J.M. Identity based views of the corporation: Insights from corporate identity, organisational identity, social identity, visual identity, corporate brand identity and corporate image. Eur. J. Mark. 2008, 42, 879-906.

53. Vlahvei, A.; Notta, O.; Grigoriou, E. Establishing a strong brand identity through a website: The case of Greek Food SMEs. Procedia Econ. Financ. 2013, 5, 771-778. [CrossRef]

54. Withers, E.T. The impact and implications of craft beer research: An interdisciplinary literature review. Craft Beverages Tour. 2017, $1,11-24$.

55. Carroll, G.R.; Swaminathan, A. Why the microbrewery movement? Organizational dynamics of resource partitioning in the US brewing industry. Am. J. Sociol. 2000, 106, 715-762. [CrossRef]

56. Hani, M.; Cheriet, F. The Mediterranean brewery industry: Consolidation, restructuring and recent developments. New Medit 2012, 11, 22-34.

57. Swaminathan, A. Entry into new market segments in mature industries: Endogenous and exogenous segmentation in the US brewing industry. Strateg. Manag. J. 1998, 19, 389-404. [CrossRef]

58. Donadini, G.; Fumi, M.D.; Kordialik-Bogacka, E.; Maggi, L.; Lambri, M.; Sckokai, P. Consumer interest in specialty beers in three European markets. Food Res. Int. 2016, 85, 301-314. [CrossRef] [PubMed]

59. O'Brien, J. The Branding Geography of Surrey Craft Breweries. In The Geography of Beer; Springer: Cham, Switzerland, 2020; pp. 23-33.

60. Bråtå, H.O. Local traditions as a means for commercial production of historical beers: The case of Vossaøl, Norway. Nor. Geogr. Tidsskr. Nor. J. Geogr. 2017, 71, 301-312. [CrossRef]

61. Hoalst-Pullen, N.; Patterson, M.W.; Mattord, R.A.; Vest, M.D. Sustainability trends in the regional craft beer industry. In The Geography of Beer; Springer: Dordrecht, The Netherlands, 2014; pp. 109-116.

62. Jones, E. Brewing green: Sustainability in the craft beer movement. In Craft Beverages and Tourism; Palgrave Macmillan: Cham, Switzerland, 2018; Volume 2, pp. 9-26.

63. Hede, A.M.; Watne, T. Leveraging the human side of the brand using a sense of place: Case studies of craft breweries. J. Mark. Manag. 2013, 29, 207-224. [CrossRef]

64. Nuessel, F. A Note on Selected Craft Beer Brand Names. Names 2018, 66, 106-115. [CrossRef]

65. Morgan, D.R.; Styles, D.; Lane, E.T. Thirsty work: Assessing the environmental footprint of craft beer. Sustain. Prod. Consum. 2021, 27, 242-253. [CrossRef]

66. Fasan, M.; Bianchi, S. (Eds.) L'azienda Sostenibile: Trend, Strumenti e Case Study; Ca'Foscari: Venice, Italy, 2017. Available online: https:/ / edizionicafoscari.unive.it/media/pdf/books/978-88-6969-202-4/978-88-6969-202-4_bRd7yhz.pdf (accessed on 24 September 2021).

67. CCIAA. Registro delle Imprese della Camera di Commercio. 2020. Available online: https://www.registroimprese.it/ (accessed on 24 September 2021).

68. ISTAT. Classificazione delle attività economiche Ateco 2007: Derivata dalla Nace Rev. 2; ISTAT, Servizio Produzione Editoriale: Avellino, Italy, 2009. Available online: http://www.istat.it/it/files/2011/03/metenorme09_40classificazione_attivita_economiche_ 2007.pdf?title=Classificazione+Ateco+2007+-+01\%2Fott\%2F2009+-+Ateco+2007+-+Volume+integrale.pdf (accessed on 24 September 2021).

69. Herring, S.C. Web content analysis: Expanding the paradigm. In International Handbook of Internet Research; Springer: Dordrecht, The Netherlands, 2009; pp. 233-249.

70. Hamzah, Z.L.; Alwi, S.F.S.; Othman, M.N. Designing corporate brand experience in an online context: A qualitative insight. J. Bus. Res. 2014, 67, 2299-2310. [CrossRef]

71. Aaker, D.A. Leveraging the corporate brand. Calif. Manag. Rev. 2004, 46, 6-18. [CrossRef]

72. Lombard, M.; Snyder-Duch, J.; Bracken, C.C. Content analysis in mass communication: Assessment and reporting of intercoder reliability. Hum. Commun. Res. 2002, 28, 587-604. [CrossRef]

73. Finch, H. Comparison of distance measures in cluster analysis with dichotomous data. J. Data Sci. 2005, 3, 85-100. [CrossRef]

74. Rousseeuw, P.J. Silhouettes: A graphical aid to the interpretation and validation of cluster analysis. J. Comput. Appl. Math. 1987, 20, 53-65. [CrossRef]

75. Meyer, D.; Buchta, C.; Meyer, M.D. Package 'Proxy'. 2021. Available online: https://CRAN.R-project.org/package=proxy (accessed on 24 September 2021).

76. Maechler, M.; Rousseeuw, P.; Struyf, A.; Hubert, M.; Hornik, K. Cluster: Cluster Analysis Basics and Extensions. R package version 2.1.2-For new features, see the 'Changelog' file (in the package source). 2021. Available online: https: / CRAN.R-project. org / package $=$ cluster (accessed on 24 September 2021).

77. Charrad, M.; Ghazzali, N.; Boiteau, V.; Niknafs, A. NbClust: An R package for determining the relevant number of clusters in a data set. J. Stat. Softw. 2014, 61, 1-36. [CrossRef] 
78. R Core Team. R: A language and Environment for Statistical Computing; R Foundation for Statistical Computing: Vienna, Austria, 2017. Available online: https:/ / www.R-project.org/ (accessed on 24 September 2021).

79. Waldrop, M.E.; McCluskey, J.J. Does information about organic status affect consumer sensory liking and willingness to pay for beer? Agribusiness 2019, 35, 149-167. [CrossRef]

80. Dressler, M.; Paunovic, I. A typology of winery SME brand strategies with implications for sustainability communication and co-creation. Sustainability 2021, 13, 805. [CrossRef]

81. Orth, U.R.; Lopetcharat, K. Consumer-based brand equity versus product-attribute utility: A comparative approach for craft beer. J. Food Prod. Mark. 2006, 11, 77-90. [CrossRef] 